\title{
COMPOSTING OF FINE FRACTION AFTER MECHANICAL- BIOLOGICAL TREATMENT OF MUNICIPAL SOLID WASTE
}

\author{
Aleksandra Anić Vučinić ${ }^{1 *}$, Valentina Tuk ${ }^{2}$, Snježana Šimunić ${ }^{3}$, Ivana Presečki ${ }^{1}$ \\ ${ }^{1}$ Faculty of Geotechnical Engineering, University of Zagreb, Hallerova aleja 7, 42000 Varaždin, Croatia \\ ${ }^{2}$ Hrvatske vode, Međimurska ulica 26b, 42000 Varaždin, Croatia \\ ${ }^{3}$ Ministry of economy and sustainable development, Radnička cesta 80, 10000 Zagreb, Croatia \\ *E-mail of corresponding author: aav@gfv.hr
}

\begin{abstract}
One of most common types of municipal solid waste treatment is mechanical-biological treatment (MBT), which in practice has many variations depending on the method of conducting the technological process and it is possible to get different output fractions. In this paper is analysed waste generated after the MBT with biodrying, where waste after mechanical treatment undergoes process of biodrying, and then is $R D F$ (recovery derived fuel) separated. Fine fraction remains with a high content of organic matter that without additional processing cannot be disposed of on a landfill.

The aim of this research was to determine the possibility of fine fraction composting in different conditions - in the open, in the open and covered area, and indoors. In each area are formed three compost piles: $100 \%$ fine fraction (KH1, KH4, and $\mathrm{KH} 7$ ), $70 \%$ fine fraction and $30 \%$ wood chips (KH2, KH5, and KH8), 50\% fine fraction and $50 \%$ wood chips (KH3, KH6, and KH9). Moisture content, temperature and dissolved organic carbon (DOC) were monitored.

Results show that after 13 weeks samples KH1, KH4, and KH7 (100\% content of fine fractions) did not achieve DOC value less than $3000 \mathrm{mg} / \mathrm{l}$. The most effective composting in terms of reducing the DOC is achieved in samples KH3, KH6, KH9.

Based on results obtained, it can be concluded that by adding wood chips in fine fraction in ratio 50:50, the most effective and fastest reduction of organic matter is achieved in the analysed samples.
\end{abstract}

Keywords: composting, mechanical - biological treatment (MBT), fine fraction, dissolved organic carbon (DOC)

Received:18.08.2021./Accepted: 27.10.2021

Published online: 01.12 .2021 .

Professional paper

https://doi.org/10.37023/ee.8.1-2.9

\section{INTRODUCTION}

Developed countries pay great attention to the waste disposal and management. The European Union requires that municipal solid waste should be processed prior of its disposal on sanitary landfills (Law on Waste Management OG 84/21). This processing is defined by physical, chemical, thermal or biological processes, including sorting, that changes the characteristics of waste in the form of reduction of its volume and its hazardous components, thus facilitating its processing (Williams, 2005).

Several countries across Europe, including Germany, Austria, Netherlands, Belgium, etc., use mechanicalbiological waste treatment (MBT) as technology to treat municipal solid waste. The aim of mechanical biological treatment of municipal solid waste is to minimise environmental impact of the disposal, to ensure separation of recyclable materials, to reduce emissions, to reduce the amount of leachate and to reduce the volume of the landfill (Soyez \& Plickert, 2002; Williams, 2005). The biological treatment in MBT refers to the microbial degradation of the organic portion of biodegradable fraction of waste that can be held with the presence of oxygen (composting) or without the presence of oxygen (anaerobic digestion), while mechanical treatment includes shredding and sorting of materials in order to separate recyclables (Williams, 2005).

One of most common types of municipal solid waste treatment is mechanical-biological treatment (MBT), which in practice has many variations depending on the method of conducting the technological process and it is possible to get different output fractions. In this paper is analysed waste generated after the MBT with biodrying, where waste after mechanical treatment undergoes process of biodrying, and RDF (refuse derived fuel) is separated. Fine fraction remains with a high content of organic matter that without additional processing cannot be disposed of on a landfill.

The aim of this research was to determine the possibility of fine fraction composting remained after biodrying in different conditions - in the open, in the open and covered area, and indoors, mixed with wood chips and without wood chips. 


\section{COMPOSTING}

The technological process of aerobic composting is complex biological - chemical process where feedstock decomposes through the action of microorganisms, mainly bacteria and fungi (Miller, 1996) during which carbon dioxide, water and heat are generated (Diaz et al., 2002; Williams, 2005; Danon et al., 2008). Microorganisms that decompose organic matter in composting process originate from the environment. They are present in composting substrates, but also in water, air, soil and in processing equipment used during the entire process. These different sources ensure presence of different groups of microorganisms which helps to maintain activity of microbial population during composting despite chemical and physical changes in material characteristics, e.g., changes in $\mathrm{pH}$ values, temperatures, moisture and organic content.

Continuous composting process can be viewed as a sequence of four phases, where each has different physical, chemical, and biological characteristics (Insam \& de Bertoldi, 2007). Mesophilic phase is characterized by a temperature range of $25^{\circ} \mathrm{C}$ to $45^{\circ} \mathrm{C}$. Bacteria, actinomycetes and fungi during this phase decompose easy degradable molecules e.g., sugars and proteins. Due to their biochemical activity temperature increases inside composting pile, while their activity decreases with temperature increase. From $45^{\circ} \mathrm{C}$ to $65^{\circ} \mathrm{C}$ during thermophile phase mesophilic microorganisms are replaces by thermophile microorganisms. This phase is important due to sanitation, respectively hygienisation of raw compost. Most of pathogenic microorganisms and weed seeds and insect eggs are removes at high temperatures, and to sanitation comes also due to actinomycetes that are used for antibiotics. Temperature starts to decrease after biodegradable substrate is exhausted in thermophile phase and cooling phase or second mesophilic phase follows. Mesophilic microorganisms are activated from remained spores and in this phase the number of microorganisms that break down cellulose and starch increases, unlike the initial mesophilic phase. In maturity phase comes to a complete change of microbial communities; number of fungi increases while number of bacteria decreases. During maturity phase are formed and dominate substances which are not degradable such as complex lignin-humus compounds. Evolution of temperatures is indicator of microbial activity during composting and this parameter can be used as a good indicator for end of bio-oxidative phase (Iglesias Jiménez \& Pérez Garcia, 1991).

The primary factors that affect the optimal environment of microbial composting process, respectively period of time and the course of the process, are: oxygenation (aeration), temperature, moisture, $\mathrm{C}: \mathrm{N}$ ratio, $\mathrm{pH}$ value in composting pile and state of the original material (de Bertoldi et al., 1983). The optimal pH value in compost is in range between 5,5 and 8. Concentrations of organic acids increase during the initial phase of composting due to activity of bacteria which decompose organic matter and produce organic acids. In successful composting and maturation of compost, $\mathrm{pH}$ values rise to 8-9 (Sundberg et al.,2004). Since the composting is biological oxidation, the availability of oxygen is very important to microorganisms. Function of aeration of compost piles includes the supply of oxygen so that it does not become a limiting factor, and this is done by mechanical turning of the piles ("windrow" systems) or by inserting perforated pipes in a compost pile that remains intact (i.e. forced aeration) (Williams, 2005).

Continued forced ventilation gives satisfactory results and enables better control over temperature and moisture of compost pile. For successful aerobic composting oxygen content should not fall below 18\% (de Bertoldi et al., 1983). Moisture content and aeration are closely related, and the optimal amount of moisture in the compost pile depends on the physical condition and particle size.

Biodegradation of small-sized substrates occurs with greater speed because of larger total area available to microorganisms. If the particles are too fine, due to finer space between them, flow and diffusion of air are hindered and anaerobic conditions can occur. If the particles are too large, process is slowed down (de Bertoldi et al., 1983). Waste material used in composting needs to be shredded if particle size is too large. Dusty materials are mixed with other, larger materials or inert materials are added to ensure ventilation of compost pile and reduction of moisture (Silva \& Naik, 2006).

\section{METHODOLOGY}

The sample on which the research was conducted is a fine fraction remained after biodrying process and RDF separation from the MBT plant. The size particles were smaller than $+25 \mathrm{~mm}$.

Analysis was conducted on nine composting piles of different composition which depended on content of subsequently added wood chips. Piles were located on three locations, in outdoor uncovered area, outdoor covered area and indoors. Temperature and moisture were measured, and laboratory measurements of dissolved organic carbon were conducted (DOC) in compost piles.

The research included daily monitoring of air temperature, precipitation, temperature, and moisture of compost piles, while on weekly basis was performed additional moistening and loosening or turning the compost piles. Compost piles were placed on three different locations and their initial characteristics (initial mass, height, and moisture content) are shown in Table 1. 
Table 1. Measurements results of compost piles $(\mathrm{KH})$ before composting process

\begin{tabular}{|c|c|c|c|c|c|c|c|c|c|}
\hline Location & \multicolumn{2}{|c|}{ Outdoor uncovered area } & \multicolumn{2}{c|}{ Outdoor covered area } & \multicolumn{3}{c|}{ Indoors } \\
\hline & KH 1 & KH 2 & KH 3 & KH 4 & KH 5 & KH 6 & KH 7 & KH 8 & KH 9 \\
\hline $\begin{array}{c}\text { Process } \\
\text { setting } \\
\text { date }\end{array}$ & $8 / 27 / 15$ & $8 / 27 / 15$ & $8 / 27 / 15$ & $8 / 27 / 15$ & $8 / 27 / 15$ & $8 / 27 / 15$ & $8 / 27 / 15$ & $8 / 27 / 15$ & $8 / 27 / 15$ \\
\hline $\begin{array}{c}\text { Initial } \\
\text { mass, kg }\end{array}$ & 5,280 & 5,048 & 5,560 & 6,336 & 7,352 & 6,950 & 5,280 & 5,718 & 5,838 \\
\hline $\begin{array}{c}\text { Height, } \\
\text { m }\end{array}$ & 1 & 1.1 & 1.5 & 1 & 1.2 & 1.2 & 1.5 & 1.6 & 1.6 \\
\hline $\begin{array}{c}\text { Moisture } \\
\text { content, } \\
\%\end{array}$ & 61.5 & 67.7 & 67.5 & 59.3 & 53 & 61.7 & 59.3 & 57.6 & 56.6 \\
\hline
\end{tabular}

Samples were taken on the beginning of the experiment from compost piles and were analysed according to Croatian regulations (Ordinance on the methods and conditions for the landfill of waste, categories and operational requirements for waste landfills, OG 114/2015).

First laboratory analysis has shown that fine fraction meets all the requirements, except that contains excessive concentration of dissolved organic carbon (DOC) and because of this, it was decided that waste is not suitable for disposal on sanitary landfill. According to the prior mentioned Ordinance, concentration of dissolved organic carbon cannot exceed $3.000 \mathrm{mg} \mathrm{kg}^{-1}$.

On weekly basis samples were collected and analysed to determine changes in DOC concentration. Compost piles on outdoor uncovered area $(\mathrm{KH} 1, \mathrm{KH} 2, \mathrm{KH} 3)$ were under the atmospheric influence which had great impact on the temperature and moisture inside the composting system. Into account were taken precipitations because research was conducted in autumn and compost piles did not have to be often humidified. The rain was falling 21 days out of total 78 days. On this location were analysed three substrates of different composition (Table 2). Fine fraction of biodegradable non-hazardous organic waste was mixed with composted wooden chops in different ratios, which affected the composting process. All compost piles were turned 14 times for aeration and that process took app. 25 minutes. Temperature of $\mathrm{KH} 1$ was in range $20-65^{\circ} \mathrm{C}$, and of $\mathrm{KH} 2$ and $\mathrm{KH} 3$ in range of $10-60$ ${ }^{\circ} \mathrm{C}$.

In outdoor covered area were analysed three compost piles (KH 4, KH 5, KH 6) of different composition in which fine fraction of biodegradable waste was mixed with composted wooden chops in different ratios. This compost piles were turned 12 timed for aeration. Temperature of $\mathrm{KH} 4$ was in range $20-65{ }^{\circ} \mathrm{C}$, of $\mathrm{KH} 5$ in range $10-60^{\circ} \mathrm{C}$ and of $\mathrm{KH} 6$ in range $20-70^{\circ} \mathrm{C}$.

Three substrates ( $\mathrm{KH} \mathrm{7,} \mathrm{KH} \mathrm{8,} \mathrm{KH} \mathrm{9)} \mathrm{of} \mathrm{different} \mathrm{composition} \mathrm{were} \mathrm{placed} \mathrm{indoors} \mathrm{and} \mathrm{for} 14$ weeks were turned 12 times for aeration. Temperature of pile $\mathrm{KH} 7$ was in range $20-70{ }^{\circ} \mathrm{C}$, and of piles $\mathrm{KH} 8$ and $\mathrm{KH} 9$ in range $30-70^{\circ} \mathrm{C}$.

\section{RESULTS AND DISCUSSION}

From total of three compost piles, containing $100 \%$ fraction of biodegradable substrate, two compost piles have not been satisfactory for further disposal on the landfill. The compost pile KH 1 was under the atmospheric influence because it was in the open uncovered area, and it is the only compost pile that managed to lose enough DOC in 14 weeks so it could be disposed on the landfill. The compost piles, KH 4 and KH 7 at the end of the research did not have a sufficiently low concentration of DOC for disposal on the landfill. All compost piles to which were added composted wood chips in different ratios (70:30 and 50:50), regardless of location, have shown satisfactory results, as presented in Table 2 . Wood chips were added to stabilize the compost material. In case that particles within the compost pile have weakened structural strength, they deform under pressure, thus reducing the volume of the air within the system. On the other hand, compost piles which contain substrate with a strong structural strength, whose individual particles will consolidate under pressure (such as wood chips, various shells, straw and hay), are more stable and less prone to deformation. If the compost material "collapsed", anaerobic conditions could occur during which composting process can slow down. Fruit waste, sludge and fertilizer are weak or have no structural strength. In that case, it is necessary to add other material which could improve the structural strength of composting material (Silva \& Naik, 2006). Any material that has a greater structural connection could be added to compost pile, whether raw or previously processed. Mass and volume of the compost pile have decreased due to the disintegration of the structure of organic materials and mineralization of organic matter during which a formation of CO2 and H20 was occurred (Breitenbeck \& Schellinger, 2004). In Table 3 are 
shown results of measurements after the end of composting process for all substrates, of which $\mathrm{KH} \mathrm{4,} \mathrm{KH} \mathrm{5,} \mathrm{KH}$ 6, KH 7, KH 8 and KH 9 have lost the weight. The compost piles of KH 1, KH 2 and KH 3 have greater weight than they had at the beginning of the experiment because they were exposed to atmospheric influence during the entire research.

Table 2. Measured concentrations of dissolved organic carbon (DOC)

\begin{tabular}{|c|c|c|c|c|c|c|c|c|c|}
\hline \multirow{2}{*}{$\begin{array}{c}\text { Compositi } \\
\text { on } \\
\text { material }\end{array}$} & Date & $\begin{array}{c}27.08 .1 \\
5 .\end{array}$ & $\begin{array}{c}09.09 . \\
15\end{array}$ & $\begin{array}{l}25.09 .1 \\
5 .\end{array}$ & $\begin{array}{l}07.10 .1 \\
5 .\end{array}$ & $\begin{array}{c}22.10 . \\
15\end{array}$ & $\begin{array}{c}05.11 . \\
15\end{array}$ & $\begin{array}{c}19.11 . \\
15\end{array}$ & \multirow{2}{*}{ Trend } \\
\hline & $\begin{array}{c}\text { Paramet } \\
\text { er }\end{array}$ & & & & & & & & \\
\hline KH 1 & $\begin{array}{c}100 \% \\
\text { fine } \\
\text { fraction }\end{array}$ & $\begin{array}{c}\text { DOC, } \\
\text { mgkg-1 }\end{array}$ & 16,709 & 15,368 & 16,469 & 11,791 & 13,118 & 6,770 & \\
\hline KH 2 & $\begin{array}{c}70 \% \\
\text { fine } \\
\text { fraction: } \\
30 \% \\
\text { wood } \\
\text { chips }\end{array}$ & $\begin{array}{c}\text { DOC, } \\
\text { mgkg-1 }\end{array}$ & 14,815 & 9,774 & 13,326 & 7,340 & 11,484 & 2,999 & \\
\hline КH 3 & $\begin{array}{c}50 \% \\
\text { fine } \\
\text { fraction: } \\
50 \% \\
\text { wood } \\
\text { chips }\end{array}$ & $\begin{array}{c}\text { DOC, } \\
\text { mgkg-1 }\end{array}$ & 7,862 & 9,809 & 16,624 & 10,311 & 6,002 & 2,637 & \\
\hline KH 4 & $\begin{array}{c}100 \% \\
\text { fine } \\
\text { fraction }\end{array}$ & $\begin{array}{l}\text { DOC, } \\
\text { mgkg-1 }\end{array}$ & 16,709 & 20,396 & 22,307 & 23,558 & 14,559 & 12,905 & \\
\hline KH 5 & $\begin{array}{c}70 \% \\
\text { fine } \\
\text { fraction: } \\
30 \% \\
\text { wood } \\
\text { chips }\end{array}$ & $\begin{array}{c}\text { DOC, } \\
\text { mgkg-1 }\end{array}$ & 14,815 & 11,815 & 16,341 & 15,447 & 10,048 & 3,587 & \\
\hline КН 6 & $\begin{array}{c}50 \% \\
\text { fine } \\
\text { fraction: } \\
50 \% \\
\text { wood } \\
\text { chips }\end{array}$ & $\begin{array}{c}\text { DOC, } \\
\text { mgkg-1 }\end{array}$ & 7,862 & 7,317 & 12,237 & 9,068 & 5,917 & 2,650 & \\
\hline КН 7 & $\begin{array}{c}100 \% \\
\text { fine } \\
\text { fraction }\end{array}$ & $\begin{array}{l}\text { DOC, } \\
\text { mgkg-1 }\end{array}$ & 16,709 & 19,635 & 26,911 & 24,196 & 19,664 & 10,076 & \\
\hline KH 8 & $\begin{array}{c}70 \% \\
\text { fine } \\
\text { fraction: } \\
30 \% \\
\text { wood } \\
\text { chips }\end{array}$ & $\begin{array}{c}\text { DOC, } \\
\text { mgkg-1 }\end{array}$ & 14,815 & 12,857 & 14,431 & 8,154 & 7,522 & 3,416 & \\
\hline КH 9 & $\begin{array}{c}50 \% \\
\text { fine } \\
\text { fraction: } \\
50 \% \\
\text { wood } \\
\text { chips }\end{array}$ & $\begin{array}{l}\text { DOC, } \\
\text { mgkg-1 }\end{array}$ & 7,862 & 7,304 & 13,343 & 12,317 & 6,025 & 3,046 & \\
\hline
\end{tabular}


Table 3. The measurement results after the end of composting process for all compost piles (KH)

\begin{tabular}{|c|c|c|c|c|c|c|c|c|c|}
\hline & \multicolumn{3}{|c|}{ Open uncovered area } & \multicolumn{2}{c|}{ Open covered area } & \multicolumn{3}{c|}{ Indoors } \\
\hline & KH 1 & KH 2 & KH 3 & KH 4 & KH 5 & KH 6 & KH 7 & KH 8 & KH9 \\
\hline \begin{tabular}{c} 
Ending date \\
\hline
\end{tabular} & $11 / 19 / 15$ & $11 / 19 / 15$ & $11 / 19 / 15$ & $11 / 19 / 15$ & $11 / 19 / 15$ & $11 / 19 / 15$ & $11 / 19 / 15$ & $11 / 19 / 15$ & $11 / 19 / 15$ \\
\hline $\begin{array}{c}\text { Mass at the end of } \\
\text { composting process, kg }\end{array}$ & 5,500 & 5,440 & 6,140 & 5,360 & 6,020 & 5,900 & 4,160 & 4,960 & 5,440 \\
\hline $\begin{array}{c}\text { Height of compost pile, } \\
\text { m }\end{array}$ & 1.28 & 1.28 & 1.28 & 1.20 & 1.28 & 1.28 & 1.28 & 1.28 & 1.28 \\
\hline \begin{tabular}{c} 
Moisture content, \% \\
\hline
\end{tabular} & 40.30 & 41.07 & 43.26 & 36.51 & 32.07 & 37.03 & 40.91 & 37.53 & 39.82 \\
\hline
\end{tabular}

The moisture content is very important variable in the composting process for bacteria because they absorb the necessary nutrients which can be dissolved in water. Too high moisture content can squeeze the air out of pore space from compost pile and lead to anaerobic conditions that do not favour composting. Too low moisture content can lead to the termination of microbial activity, regarding their deaths (Silva \& Naik, 2006).

Some research shows that total duration of organic matter of municipal solid waste (MSW) bio stabilization ranged from 42 to 135 days, including the intensive phase carried out in closed reactors for 18 to 84 days, and the phase of saturation in windrows, which lasted for 13 to 63 days (Jedrezak\&Suchowska-Kisielewicz 2018) what this research confirmed for heavy fraction of MSW after MBT treatment.

\section{CONCLUSION}

This research was conducted to determine possibilities of processing the fine fraction of biodegradable substrate of non-hazardous organic waste that should be suitable for landfill disposal. In this research, "windrow" composting method was used, which main characteristic is that the raw material is accumulated in compost piles that occupy a lot of space, so it is necessary to loosen it. Satisfactory supply of aeration is necessary for almost all composting system. Starting aeration process in 'windrow' compost method is achieved with the processing and stacking of raw waste. Composting was conducted on three different locations with different ratios of wooden chips. Fourteen weeks were determined for composting process and in that time in almost all compost piles (except compost piles KH 4 and $\mathrm{KH} 7$ ) value of DOC has been decreased and the requirement for disposal on the landfill was met. As the best location for composting has proven to be an open area for all compositions since all analysis results of compost piles have met the limit values of the effluent parameters of the waste defined with the Ordinance (OG 114/15).

\section{REFERENCES}

Bertoldi, M. de, Vallini, G. \& Pera, A. (1983) The Biology of Composting: A review. Waste managment \& research, 1, 157-176.

Breitenbeck G. A., \& Schellinger D. (2004) Calculating the Reduction in Material Mass And Volume during Composting. Compost Science \& Utilization, 12:4, 365-371.

Danon, M., Franke-Whittle, I. H., Insam, H., Chen, Y. \& Hadar, Y. (2008) Molecular analysis of bacterial community succession during prolonged compost curing. FEMS Microbiol Ecol, 65, 133-144, Blackwell Publishing Ltd.

Diaz, L.F., Savage, G.M. \& Golueke, C. G. (2002) Chapter Twelve, Composting of Municipal Solid Wastes. In: Handbook of Solid Waste Management, Second Edition (eds.: Tchobanoglobus, G. \& Kreith, F.), 12.1-12.70, McGraw-Hill Companies, Inc., New York.

Iglesias Jiménez, E. \& Pérez Garcia, V. (1991) Composting of domestic refuse and sewage sludge. I. Evolution of temperature, $\mathrm{pH}, \mathrm{C} / \mathrm{N}$ ratio and cation-exchange capacity. Resources, Conservation and Recycling, 6, 45-60, Elsevier Science Publishers B. V./Pergamon Press Plc.

Insam, H. \& Bertoldi, M. de (2007) Microbiology of the Composting Process. In: Compost science and technology, Waste Managment Series, V 8 (eds.: Diaz, L.F., Bertoldi, M. de, Bidlingmaier, W. \& Stentiford, E.), 26-45, Elsevier Ltd. 
Jadrezak, A. \&Suchowska-Kisielewicz, M. (2018) A Comparison of Waste Stability Indices for MechanicalBiological Waste Treatment and Composting Plants. Internationa Journal of Environmental Research and Public Health, 1-13, MDPI.

Miller, F. C. (1996) Composting of Municipal Solid Waste and its Compopnents. In: Microbiology of Solid Waste (eds.: Palmisano, A. C. \& Barlaz, M. A.), 115-154, CRC Press Inc.

Ordinance on the methods and conditions for the landfill of waste, categories and operational requirements for waste landfills, OG 114/2015

Silva M. R. Q. \& Naik T. R. (2006): Overview of Composting - Fundamentals and Processes (https://www4.uwm.edu/cbu/Papers/2006\%20CBU\%20Reports/REP-613.pdf (accessed April 13, 2016)

Soyez, K. \& Plickert, S. (2002) Mechanical-Biological Pre-Treatment of Waste: State of the Art and Potentials of Biotechnology. Acta Biotechnol, 22, 3-4, 271-284.

Sundberg, C., Smårs S. \& Jönsson H. (2004) Low pH as an inhibiting factor in the transition from mesophilic to thermophilic phase in composting. Bioresource Technology, 95, 145-150, Elsevier Ltd.

Williams, P.T. (2005) Waste Treatment and Disposal, Second edition. I-IX, 1-375, John Wiley \& Sons Ltd, Chichester.

The Law on Sustainable Waste Management (Offical Gazette NN 94/13) 